\title{
Does Research Reduce Poverty? Assessing the Impacts of Policy- oriented Research in Agriculture
}

\author{
Andy Sumner, Edoardo Masset and Rajendra Mulmi
}

Abstract In the current context of the global financial crisis and its aftermath, development resources are likely to be getting scarcer. Resources for development research are too. The set of circumstances generating the resource scarcity is also putting pressure on development gains. More than ever before, every dollar spent on development will have to count towards sustainable poverty reduction, as will every dollar spent on development research. In light of this context this article asks what do we know about the welfare impacts of research in agriculture?

\section{Introduction}

There are three main reasons for assessing the policy impact of research: auditing, learning and cost-effectiveness analysis. Impact assessment of policy research will help ascertain:

- whether a particular project has the desired impact on policy (auditing)

- what are the main factors affecting programme success and failure (learning)

- what is the cost of achieving the outcomes compared to other interventions (costeffectiveness).

Programme assessment along these lines will help programme managers to discontinue ineffective programmes, to improve the operations of future interventions, and to choose among alternative interventions having the same goals. Exploring conditions to improve existing evaluations of welfare impacts of policy interventions is highly desirable.

In this article we review the literature on impact assessments of 'policy-oriented' research in agriculture.' Our article seeks to build on the work of others, notably, IFPRI, CGIAR, IDRC, ODI RAPID, GDN, NR International and ECDPM. Indeed, the area of research impact is not a new area of enquiry but an emergent one (see for broad-sweeping introduction Sumner et al. 2009).

\section{Studies of agriculture research impact assessment 2.1 Studies chosen}

We identified 13 studies of agriculture research impact assessment (see Table 1). Each study is a study of the impact of an earlier piece of policyoriented research.

These 13 studies cover a range of country contexts - Bangladesh, Indonesia, Jordan, Kenya, Malawi, Mexico, the Philippines, Syria, Uganda and Viet Nam - as well as a range of policy changes rationing, food for education, pulp and paper policy, barley fertilisation, conditional cash transfers, dairy marketing, fisheries management, rice marketing, food security, pesticides, water management and urban agriculture and a range of welfare impacts including agriculture productivity, schooling and consumer surpluses.

Most impact studies of policy research in agriculture reveal that analysing attribution and influence of 'policy-oriented' research is certainly not an easy task. As earlier noted, there is 'uncertainty in determining a causal link between research and the outcome of a policy or the value of a policy outcome' (Timmer 1998: 11) and there is difficulty of quantifying the actual policy or welfare impact. All studies reviewed found severe difficulties in assessing impact on welfare outcomes and either renounced doing so 
or assessed impact under a number of heroic assumptions.

The majority of the studies reviewed employed either a policy evaluation approach, which assumes that research determines policy change and studies the effect of this policy change on welfare indicators, or an economic modelling approach, which looks at the effect of research on welfare directly, ignoring the complications and subtleties implied by the policy process.

The research reviewed on policy impacts of agriculture policy-oriented projects has involved, in almost all cases, qualitative approaches and studies of people's perceptions (except one case where a combination of episode study, case study and outcome mapping was undertaken). Qualitative approaches are useful when they provide retrospective narratives that illustrate how research influences policy (Ryan and Garrett 2003: 2-3). Case studies provide rich, qualitative data for analysis and are the most used approach in assessing how research interacts, influences and impacts policy processes in any particular context.

Key informant interviews have been the widely preferred tool in all of these cases. These interviews have been taken either face to face, by telephone or email. The CGIAR (2008: 84) observes that 'the studies that relied on singleinterviewer taped conversations seemed to establish more credibility on the issue of influence than those that drew solely on written questionnaires, especially mailed-in responses'.

In each of these 13 studies it is possible to identify the 'vision of success' (VoS), the 'preconditions' and the 'interventions'. Table 2 lists the 'visions' used.

In some cases the studies are based solely on policy impacts as the 'vision of success' (and it is assumed welfare impacts follow); in other studies it is both policy impacts and welfare outcomes. For example, welfare impacts include agricultural productivity, environmental benefits or improvements in schooling. These might be thought of as 'end-goal visions of success'. In contrast, policy impacts might be labelled an 'intermediate vision of success' and include policy change, changes in policy implementation and other policy changes outlined earlier.

\section{2 'Pre-conditions'}

We listed the 'pre-conditions' in each of the 13 studies. For example, aspects highlighted relating to policy actors such as the existence of policy 'champions' in government and support from donors in terms of funding and influence.

Aspects relating to the policy narrative highlighted were the already existing credibility of research organisations and researchers built in the long run and research conforming to policymakers' expectations.

Finally, there are 'pre-conditions' relating to the policy context highlighted such as a conducive policy environment and receptiveness towards research, demand for research-generated evidence and the long-standing presence of research institutions and their programmes.

However, it is important to note that one of the difficulties in comparing various studies is that they employ different frameworks for analysis. For example, while some studies explicitly examine the policy actors, narratives and context (e.g. Hooton et al. 2007), other studies such as those that are part of CGIAR (2008) use a method (the Impact Pathways Method) which does not necessarily capture these aspects in a comparable way.

\section{3 'Interventions'}

We listed the 'interventions' in each of the 13 studies. All the projects that funded these studies made explicit attempts to inform policy and had well-designed communication strategies. In terms of networking, agricultural policyoriented research collaboration and engagement of a range of policy and decision-makers become very important. For example:

- Researchers worked in collaboration with the Ministry of Agriculture and Rural Development in the case of rice policy change in Viet Nam.

- In Bangladesh researchers collaborated with decision-makers and operated within the decision-making system to facilitate their use of information.

- In Syria researchers linked up with one key 'policy champion' who was a member of the Fertilizer Allocation Committee. 


\begin{tabular}{|c|c|c|c|c|}
\hline $\begin{array}{l}\text { Impact assessment } \\
\text { (details and } \\
\text { reference) }\end{array}$ & $\begin{array}{l}\text { Study which the } \\
\text { impact assessment } \\
\text { explored }\end{array}$ & $\begin{array}{l}\text { Type of impact } \\
\text { assessment and } \\
\text { timing }\end{array}$ & $\begin{array}{l}\text { Overall VoS: } \\
\text { welfare impacts }\end{array}$ & $\begin{array}{l}\text { Intermediate VoS: } \\
\text { policy impact }\end{array}$ \\
\hline $\begin{array}{l}\text { Rural Rationing (RR) } \\
\text { programme in } \\
\text { Bangladesh } \\
\text { Babu (2000) }\end{array}$ & Ahmed (1992) & $\begin{array}{l}\text { Policy evaluation } \\
\text { Closure + elapsed } \\
\text { time ( } 6 \text { years) }\end{array}$ & $\begin{array}{l}\text { No welfare impact. The } \\
\text { abolition of a wasteful } \\
\text { and inefficient food } \\
\text { delivery programme } \\
\text { generates project savings }\end{array}$ & $\begin{array}{l}\text { Policy content } \\
\text { impact - May } 1992 \text { - } \\
\text { decision to abolish } \\
\text { the Rural Rationing } \\
\text { Programme }\end{array}$ \\
\hline $\begin{array}{l}\text { Food for Education } \\
\text { programme (FFE) in } \\
\text { Bangladesh } \\
\text { Babu (2000) }\end{array}$ & $\begin{array}{l}\text { Ahmed and Billah } \\
\text { (1994) }\end{array}$ & $\begin{array}{l}\text { Policy evaluation } \\
\text { Closure + elapsed } \\
\text { time (4 years) }\end{array}$ & $\begin{array}{l}\text { Increase enrolment } \\
\text { and school attendance } \\
\text { of children assisted by } \\
\text { a school feeding } \\
\text { programme. The impact } \\
\text { on per capita calories } \\
\text { consumption is simulated }\end{array}$ & $\begin{array}{l}\text { Behavioural change } \\
\text { in policy } \\
\text { implementation } \\
\text { - 1994/95 - decision } \\
\text { to expand the FFE } \\
\text { programme } \\
\text { d }\end{array}$ \\
\hline $\begin{array}{l}\text { In-Trust Agreement } \\
\text { between FAO and } \\
\text { CGIAR } \\
\text { Gotor et al. (2008) }\end{array}$ & $\begin{array}{l}\text { Siebeck and Barton } \\
\text { (1992) }\end{array}$ & $\begin{array}{l}\text { Policy evaluation } \\
\text { Closure + elapsed } \\
\text { time ( } 6 \text { years) }\end{array}$ & $\begin{array}{l}\text { Agricultural productivity, } \\
\text { but not quantified }\end{array}$ & $\begin{array}{l}\text { Policy framing } \\
\text { impact - } 1994 \text { - } \\
\text { In-Trust Agreement } \\
\text { established between } \\
\text { FAO and CGIAR }\end{array}$ \\
\hline $\begin{array}{l}\text { Pulp and Paper Policy } \\
\text { in Indonesia } \\
\text { Raitzer (2008) }\end{array}$ & Barr (2000, 2001) & $\begin{array}{l}\text { Economic modelling } \\
\text { and policy evaluation } \\
\text { Closure }+6 \text { years }\end{array}$ & $\begin{array}{l}\text { Environmental benefits } \\
\text { in terms of forest area } \\
\text { saved and other } \\
\text { external factors }\end{array}$ & $\begin{array}{l}\text { Policy procedural } \\
\text { impact - } 2003- \\
\text { Ministerial decree } \\
\text { adopted requiring } \\
\text { Indonesia's pulp mills } \\
\text { to source all its } \\
\text { wood from } \\
\text { plantations by } 2009\end{array}$ \\
\hline $\begin{array}{l}\text { Barley Fertilisation } \\
\text { Policy in Syria } \\
\text { Shideed et al. (2008) }\end{array}$ & El-Hajj et al. (1990) & $\begin{array}{l}\text { Economic modelling } \\
\text { Closure }+17 \text { years }\end{array}$ & $\begin{array}{l}\text { Change in consumer } \\
\text { surplus in the barley } \\
\text { market }\end{array}$ & $\begin{array}{l}\text { Behavioural changes } \\
\text { in policy } \\
\text { implementation - } \\
1989 \text { - New } \\
\text { fertiliser allocation } \\
\text { policy implemented }\end{array}$ \\
\hline $\begin{array}{l}\text { PROGRESA Anti- } \\
\text { poverty and Human } \\
\text { Resource Investment } \\
\text { Conditional Cash } \\
\text { Transfer Programme } \\
\text { in Mexico } \\
\text { Behrman (2007) }\end{array}$ & $\begin{array}{l}\text { Behrman and } \\
\text { Hoddinott (2000) }\end{array}$ & $\begin{array}{l}\text { Policy evaluation } \\
\text { during programme }\end{array}$ & Children's schooling & $\begin{array}{l}\text { Policy framing } \\
\text { impact - } 2000- \\
\text { Continuation of } \\
\text { PROGRESA } \\
\text { programme by } \\
\text { Mexican } \\
\text { Government }\end{array}$ \\
\hline $\begin{array}{l}\text { Dairy Marketing Policy } \\
\text { in Kenya } \\
\text { Kaitibie et al. (2008) }\end{array}$ & $\begin{array}{l}\text { SDP publications: } \\
\text { research reports, } \\
\text { policy briefs and May } \\
2004 \text { Dairy Policy } \\
\text { Forum organised by } \\
\text { SDP and partners. }\end{array}$ & $\begin{array}{l}\text { Economic modelling } \\
\text { Closure + time lapse } \\
\text { ( } 2 \text { years) }\end{array}$ & $\begin{array}{l}\text { Change in consumer } \\
\text { surplus in the milk } \\
\text { market }\end{array}$ & $\begin{array}{l}\text { Policy procedural } \\
\text { impact - } 2004-\text { a } \\
\text { set of dairy industry } \\
\text { regulations was } \\
\text { issued }\end{array}$ \\
\hline $\begin{array}{l}\text { Pesticide Package } \\
\text { Programme (PPP) in } \\
\text { Philippines } \\
\text { Templeton and } \\
\text { Jamora (2008) }\end{array}$ & $\begin{array}{l}\text { Márquez et al. (1990); } \\
\text { Pingali and Márquez } \\
\text { (1990); Pingali and } \\
\text { Palis (1990); Antle and } \\
\text { Pingali (1991); Pingali } \\
\text { et al. (1995); Pingali } \\
\text { and Roger (1995) }\end{array}$ & $\begin{array}{l}\text { Economic modelling } \\
\text { and policy evaluation } \\
\text { Closure + elapsed } \\
\text { time (16 years) }\end{array}$ & $\begin{array}{l}\text { Expenditure (measured } \\
\text { in savings resulting } \\
\text { from fall in pesticide } \\
\text { use and savings from } \\
\text { reduction in health cost } \\
\text { after reduction in } \\
\text { toxicity of production } \\
\text { process) }\end{array}$ & $\begin{array}{l}\text { Policy content } \\
\text { impact - } 1992 \text { - } \\
\text { Pesticide Policy } \\
\text { Package }\end{array}$ \\
\hline
\end{tabular}




\begin{tabular}{|c|c|c|c|c|}
\hline $\begin{array}{l}\text { Impact assessment } \\
\text { (details and } \\
\text { reference) }\end{array}$ & $\begin{array}{l}\text { Study which the } \\
\text { impact assessment } \\
\text { explored }\end{array}$ & $\begin{array}{l}\text { Type of impact } \\
\text { assessment and } \\
\text { timing }\end{array}$ & $\begin{array}{l}\text { Overall VoS: } \\
\text { welfare impacts }\end{array}$ & $\begin{array}{l}\text { Intermediate VoS: } \\
\text { policy impact }\end{array}$ \\
\hline $\begin{array}{l}\text { Community-based } \\
\text { Fisheries } \\
\text { Management (CBFM) } \\
\text { in Bangladesh } \\
\text { Pemsl et al. (2008) }\end{array}$ & $\begin{array}{l}\text { Various publications } \\
\text { (see list in Pemsl et al. } \\
\text { 2008) }\end{array}$ & $\begin{array}{l}\text { Preconditions testing } \\
\text { Closure }\end{array}$ & $\begin{array}{l}\text { Increase in income from } \\
\text { fisheries and other } \\
\text { positive environmental } \\
\text { effects - but the } \\
\text { effects were not } \\
\text { quantified }\end{array}$ & $\begin{array}{l}\text { Behavioural changes } \\
\text { in policy } \\
\text { implementation - } \\
\text { ongoing - Changes } \\
\text { in opinion and } \\
\text { awareness of CBFM } \\
\text { among relevant } \\
\text { policymakers }\end{array}$ \\
\hline $\begin{array}{l}\text { Rice Marketing Policy } \\
\text { in Viet Nam } \\
\text { Ryan (1999a) }\end{array}$ & $\begin{array}{l}\text { IFPRI (1996) } \\
\text { Goletti and Minot } \\
\text { (1997), Minot and } \\
\text { Goletti (1997, 1998). }\end{array}$ & $\begin{array}{l}\text { Economic modelling } \\
\text { Closure + elapsed } \\
\text { time (one year) }\end{array}$ & $\begin{array}{l}\text { Changes in poverty } \\
\text { simulated by estimated } \\
\text { changes in production, } \\
\text { prices, and volume of } \\
\text { trade }\end{array}$ & $\begin{array}{l}\text { Policy content } \\
\text { impact - } 1998 \text { - } \\
\text { New rice marketing } \\
\text { policy implemented }\end{array}$ \\
\hline $\begin{array}{l}\text { Community based } \\
\text { food security and } \\
\text { capacity building in } \\
\text { Malawi } \\
\text { Ryan (1999b) }\end{array}$ & $\begin{array}{l}\text { Various publications } \\
\text { (Ryan 1999b) }\end{array}$ & $\begin{array}{l}\text { Preconditions testing } \\
\text { Closure }\end{array}$ & $\begin{array}{l}\text { Malnutrition and } \\
\text { mortality, but the } \\
\text { effects are not } \\
\text { quantified }\end{array}$ & $\begin{array}{l}\text { Policy framing } \\
\text { impact - early } 1990 \text { s } \\
\text { - awareness within } \\
\text { the government of } \\
\text { Malawi of the need } \\
\text { for community- } \\
\text { based food security } \\
\text { and monitoring } \\
\text { systems. Establish } \\
\text { Master's degree } \\
\text { programme at } \\
\text { Bunda College of } \\
\text { Agriculture, degree } \\
\text { established in } 1994\end{array}$ \\
\hline $\begin{array}{l}\text { Greywater Reuse in } \\
\text { Jordan } \\
\text { Surani (2003) }\end{array}$ & $\begin{array}{l}\text { Faruqui and } \\
\text { Al-Jayyousi (2002); } \\
\text { Faruqui (2003); }\end{array}$ & $\begin{array}{l}\text { Policy evaluation } \\
\text { Closure }\end{array}$ & $\begin{array}{l}\text { No welfare outcomes } \\
\text { are quantified }\end{array}$ & $\begin{array}{l}\text { Policy procedural } \\
\text { impact - } 2003- \\
\text { Revision of the } \\
\text { National Housing } \\
\text { Codes and } \\
\text { formation of a } \\
\text { National Committee } \\
\text { to formulate } \\
\text { Greywater Reuse } \\
\text { Guidelines }\end{array}$ \\
\hline $\begin{array}{l}\text { Urban Agriculture } \\
\text { Ordinances in } \\
\text { Uganda } \\
\text { Hooton et al. (2007) }\end{array}$ & $\begin{array}{l}\text { Maxwell (1994, 1995); } \\
\text { Van Nostrand (1994); } \\
\text { Atukunda (1998); } \\
\text { Urban Harvest (2005) }\end{array}$ & $\begin{array}{l}\text { Preconditions } \\
\text { Closure + elapsed } \\
\text { time (since there are } \\
\text { various pieces of } \\
\text { research the exact } \\
\text { number of years varies) }\end{array}$ & $\begin{array}{l}\text { Food security, but } \\
\text { impact is not quantified }\end{array}$ & $\begin{array}{l}\text { Policy content } \\
\text { impact }-A \text { set of } \\
\text { five new ordinances } \\
\text { on urban agriculture } \\
\text { passed }\end{array}$ \\
\hline
\end{tabular}

In terms of 'messaging', in all of the cases of policy impact of research, it is seen that documentation and dissemination of research findings is one key element to influence policymakers. The research outputs can take various forms such as reports, papers, training manuals, posters, policy briefs, journal publications and conference presentations. In almost all the cases, a series of workshops, conferences and seminars were organised to disseminate the research findings. This is not a one-time effort. In almost all of the cases there have been several publications and dissemination events targeting various stakeholders and policymakers at various levels. 


\begin{tabular}{|c|c|c|c|}
\hline $\begin{array}{l}\text { Approach and } \\
\text { examples }\end{array}$ & Key variables & $\begin{array}{l}\text { The 'how' } \\
\text { - methodology and methods }\end{array}$ & The 'when' \\
\hline $\begin{array}{l}\text { Policy evaluation } \\
\text { approach } \\
\text { Fan et al. (2003); } \\
\text { Ryan (1999a) }\end{array}$ & $\begin{array}{l}\text { Income } \\
\text { Poverty } \\
\text { Mortality } \\
\text { Nutritional status }\end{array}$ & $\begin{array}{l}\text { This approach performs an impact } \\
\text { assessment of a policy or project } \\
\text { (using standard quantitative evaluation } \\
\text { techniques). It identifies to what } \\
\text { extent that policy or programme was } \\
\text { the result of research (via surveys or } \\
\text { other empirical methods). It simulates } \\
\text { the impact of the project or policy } \\
\text { effect on welfare indicators (often } \\
\text { using parameters obtained from other } \\
\text { studies). }\end{array}$ & $\begin{array}{l}\text { After project } \\
\text { completion }\end{array}$ \\
\hline $\begin{array}{l}\text { Preconditions } \\
\text { testing approach } \\
\text { Weiss and } \\
\text { Bucuvalas (1980) }\end{array}$ & $\begin{array}{l}\text { The 'quality' of research (e.g. } \\
\text { standardisation of techniques and } \\
\text { rigorous research processes) } \\
\text { and/or the quality of leadership } \\
\text { in terms of a decision-maker's } \\
\text { ability to make judgements } \\
\text { on research 'quality' }\end{array}$ & $\begin{array}{l}\text { This approach tests functional } \\
\text { relationships between links in the } \\
\text { causal chain that runs from research to } \\
\text { welfare (by using survey data or } \\
\text { behavioural experimental methods). }\end{array}$ & $\begin{array}{l}\text { After project } \\
\text { completion and } \\
\text { (experimentally) any } \\
\text { time before and } \\
\text { after the project }\end{array}$ \\
\hline $\begin{array}{l}\text { Economic } \\
\text { modelling } \\
\text { approach } \\
\text { See review by } \\
\text { Alston et al. (2000) }\end{array}$ & $\begin{array}{l}\text { Crop production } \\
\text { Consumer surplus } \\
\text { Producer surplus }\end{array}$ & $\begin{array}{l}\text { This approach assesses the economic } \\
\text { impact of research on producers and } \\
\text { consumers of a particular commodity. } \\
\text { Producers benefit through cost } \\
\text { reductions but are affected by prices. } \\
\text { Consumers benefit via price reductions. } \\
\text { The changes in producer and consumer } \\
\text { surplus can then be used to simulate } \\
\text { the reduction in poverty or other } \\
\text { welfare effects. The methods used are } \\
\text { IRR (internal rate of return) and } \\
\text { regression analysis. }\end{array}$ & $\begin{array}{l}\text { Several years } \\
\text { after project } \\
\text { completion }\end{array}$ \\
\hline
\end{tabular}

Note These approaches are about welfare impacts. It is possible simply to focus solely on policy impacts.

In terms of opportunism, the identification of a favourable environment for adoption of the new policy is crucial. For example, in Bangladesh the timing of research coincided with the need for information. It is also seen from the cases that no matter how robust the research findings are, unless there is a favourable policy environment consisting of a strong political will, a receptiveness to change, and the existence of trust between and among those most responsible for policy, the adoption or changes of policy becomes difficult as shown by the case of IRRI (International Rice Research Institute) research in Philippines. In the case of Malawi, UNICEF's persistent call for greater attention to the food insecurity problems and malnutrition in the 1980 s created a receptive environment in which the government sought research to inform policy choices.

Three factors that one could draw from the set of 13 studies and interventions or what researchers can do to maximise their chances of impact are (i) 'saturation' - a high volume of written outputs and workshops/seminars, etc.;

(ii) 'recognition' - of a conducive political environment if it exists; and (iii) 'relationships' building long-term relationships to become a 'trusted source'.

\section{Conclusions}

The review of the agricultural research impact studies suggests that there is no standard practice for the evaluation of research. The 
review, however, also concluded that provided we are willing to accept some assumptions, it is possible to test research project impacts along some dimensions of project operations by finding the appropriate indicators (and methodology). The overall goal - welfare impacts of research is highly desirable but not always feasible. This type of assessment is made difficult by the time lag in the occurrence of welfare effects after the interventions, the availability of data to measure project effects or to perform simulations, and the theoretical problems of building a valid counterfactual and of identifying the determinants of success.

When a welfare assessment of research projects is not feasible, it is recommended that evaluators

\section{Note}

1 A longer version of this article is available in Sumner et al. (2010 forthcoming). The authors would like to thank in particular Lawrence

\section{References}

Ahmed, A. (1992) Operational Performance of the Rural Rationing Program in Bangladesh, Working Paper on Bangladesh 5, Washington DC: International Food Policy Research Institute (IFPRI)

Ahmed, A. and Billah, K. (1994) Food for Education Program in Bangladesh: An Early Assessment, Manuscript 62, Bangladesh Food Policy Project, Dhaka: International Food Policy Research Institute (IFPRI)

Alston, J.M.; Chan-Kang, C.; Marra, M.C.; Pardey, P.G. and Wyatt, T.J. (2000) A MetaAnalysis of Rates of Return to Agricultural RED, Research Report 113, Washington DC: International Food Policy Research Institute (IFPRI)

Antle, J.M. and Pingali, P.L. (1991) 'Pesticides, Farmer Health and Productivity: A Philippine Case Study', paper presented at the International Association of Agricultural Economists, 22-29 August 1991, Tokyo. IRRI Social Sciences Division Paper No. 91-10, Los Baños, Laguna, the Philippines: International Rice Research Institute (IRRI)

Atukunda, G. (1998) Urban Agriculture in Kampala, Uganda: Reviewing Research Impacts, IDRC Cities Feeding People Report 29B, Canada: International Development Research Centre (IDRG), www.idrc.ca/en/ev-8249-201-1DO_TOPIC.html (accessed 10 August 2010) test intermediate project outcomes. The articulation of the theory of change of the project allows testing critical links in the causal chain running from research to welfare. In particular, what emerges from the review is the need to assess the impact of research on policy change. More effort should be spent in designing surveys of policymakers that allow a more accurate attribution of a given policy to research.

Finally, when the research-policy attribution problem is not easily approachable, an alternative method of assessing impact consists of testing the presence of fundamental preconditions for the success of research in influencing policies.

Haddad and Johanna Lindstrom for important comments on several earlier drafts of this and the longer article, as well as Nicola Jones and Nick Perkins for ongoing discussions.

Babu, S. (2000) Impact of IFPRI's Policy Research on Resource Allocation and Food Security in Bangladesh, Impact Assessment Discussion Paper 13, Washington DC: International Food Policy Research Institute (IFPRI)

Barr, C. (2001) Banking on Sustainability: Structural Adjustment and Forestry Reform in Post-Soeharto Indonesia, Bogor, Indonesia: Center for International Forestry Research (CIFOR) and WWF-International Macroeconomics for Sustainable Development Program Office

Barr, C. (2000) Profits on Paper: The Political Economy of Fiber, Finance and Debt in Indonesia's Pulp and Paper Industries, Bogor, Indonesia: Center for International Forestry Research (CIFOR) and WWF-International Macroeconomics for Sustainable Development Program Office

Behrman, J.R. (2007) Policy-oriented Research Impact Assessment (PORIA) Case Study on the International Food Policy Research Institute (IFPRI) and the Mexican PROGRESA Anti-poverty and Human Resource Investment Conditional Cash Transfer Program, IFPRI Impact Assessment Discussion Paper 27, Washington DC: International Food Policy Research Institute (IFPRI)

Behrman, J.R. and Hoddinott, J. (2000) An Evaluation of the Impacts of PROGRESA on Preschool Child Height, Washington DC:

International Food Policy Research Institute (revised version published as Behrman and Hoddinott 2005) 
GGIAR (CGIAR Science Council) (2008) Impact Assessment of Policy-Oriented Research in the CGIAR: Evidence and Insights from Case Studies, study commissioned by the Science Council Standing Panel on Impact Assessment, Rome: CGIAR Science Council Secretariat

El-Hajj, K.; Saade M. and Meda, L. (1990) Economic Analysis for Fertilizer Allocation Strategies in Syria: Fertilizers Requirement and Allocation Strategies of Main Crops in Syria, Aleppo, Syrian Arab Republic: International Center for Agricultural Research in the Dry Areas (ICARDA) [in Arabic]

Fan, S.; Chan-Kang, C.; Quian, K. and Krishnaiah, K. (2003) National and International Agricultural Research and Rural Poverty: The Case of Rice Research in India and China, EPTD Discussion Paper 109, Washington DC: International Food Policy Research Institute (IFPRI)

Faruqui, N. (2003) Summary of IDRC-funded Research on Greywater Projects in the MENA Region, IDRG Concept Paper submitted to International Fund for Agricultural Development (IFAD)

Faruqui, N. and Al-Jayyousi, O. (2002) 'Greywater Reuse in Urban Agriculture for Poverty Alleviation: A Case-Study in Jordan', Water International 27.3: 387-94

Goletti, F. and Minot, N. (1997) From Famine to Surplus: Past Trends and Future Challenges of the Rice Economy of Viet Nam, paper prepared for a book manuscript for the International Food Policy Research Institute, Washington DC

Gotor, E.; Caracciolo, F. and Watts, J. (2008) 'The Impact of the In-Trust Agreements on CGIAR Germplasm Exchange and the Role of Bioversity International in Establishing the Agreements', in CGIAR Science Council, Impact Assessment of Policy-Oriented Research in the CGIAR: Evidence and Insights from Case Studies, study commissioned by the Science Council Standing Panel on Impact Assessment, Rome: GGIAR Science Council Secretariat

Hooton, N.; Lee-Smith, D.; Nasinyama, G. and Romney, D., in collaboration with Atukunda, G.; Azuba, M.; Kaweesa, M.; Lubowa, A.; Muwanga, J.; Njenga, M. and Young, J. (2007) Championing Urban Farmers in Kampala: Influences on Local Policy Change in Uganda, ILRI Research Report 2, in collaboration with ODI, Urban Harvest and KUFSALCG, International Livestock Research Institute, Nairobi, Kenya

IFPRI (International Food Policy Research Institute) (1996) Rice Market Monitoring and
Policy Options Study, paper prepared as End-ofAssignment Report to the Asian Development Bank for TA No. 2224-VIE, December

Kaitibie, S.; Omore, A.; Rich, K.; Salasya, B.; Hooten, N.; Mwero, D. and Kristjanson, P. (2008) 'Policy Change in Dairy Marketing in Kenya: Economic Impact and Pathways to Influence from Research', in CGIAR Science Council, Impact Assessment of Policy-Oriented Research in the CGIAR: Evidence and Insights from Case Studies, study commissioned by the Science Council Standing Panel on Impact Assessment, Rome: CGIAR Science Council Secretariat Maxwell, D. (1995) 'Land, Labor, Food, and Farming: A Household Analysis of Urban Agriculture in Kampala, Uganda', $\mathrm{PhD}$ dissertation, University of Wisconsin-Madison, USA

Maxwell, D. (1994) 'The Household Logic of Urban Farming in Kampala', in Cities Feeding People - An Examination of Urban Agriculture in East Africa, Canada: International Development Research Centre (IDRG)

Márquez, C.B.; Pingali, P.L.; Palis, F.G.; Rodriguez, V.C. and Ramos, M.G.P. (1990) 'Evaluation of the Health Effects of Pesticide Use Among Laguna Farmers', in Proceedings of the Workshop on Environmental and Health Impacts of Pesticide Use in Rice Culture, 28-30 March 1990, Los Baños, the Philippines: International Rice Research Institute (IRRI)

Minot, N. and Goletti, F. (1998) 'Export Liberalization and Household Welfare: The Case of Rice in Viet Nam', American Journal of Agricultural Economics 80.4: 738-49

Minot, N. and Goletti, F. (1997) Impact of Rice Export Policy on Domestic Prices and Food Security: Further Analysis Using VASEM, paper prepared for the World Bank, July

Pemsl, D.E.; Seidel-Lass, L.; White, J.L. and Ahmed, M.M. (2008) 'Community-based Fisheries Management Project in Bangladesh', in CGIAR Science Council, Impact Assessment of Policy-Oriented Research in the CGIAR: Evidence and Insights from Case Studies, study commissioned by the Science Council Standing Panel on Impact Assessment, Rome, Italy: CGIAR Science Council Secretariat

Pingali, P.L. and Márquez, C.B. (1990) Health Costs of Long-Term Pesticide Exposure in the Philippines - A Medical and Economic Analysis, IRRI Social Sciences Division Paper 90-04, Los Baños, Laguna, the Philippines: International Rice Research Institute (IRRI) 
Pingali, P.L. and Palis, F.G. (1990) 'Impact of Pesticides on the Environment and Human Health: A Preliminary Assessment in the Philippines', paper presented at the Annual Meeting of the American Association for the Advancement of Science, New Orleans, LA, USA, 22-25 February 1990, Los Baños, the Philippines: International Rice Research Institute (IRRI)

Pingali, P.L. and Roger, P.A. (eds) (1995) Impact of Pesticides on Farmers' Health and the Rice Environment, Norwell, MA: Kluwer Academic Publishers and Los Baños, the Philippines: International Rice Research Institute (IRRI)

Pingali, P.L.; Márquez, C.B.; Palis, F.G. and Rola, A.C. (1995) 'The Impact of Pesticides on Farmer Health: A Medical and Economic Analysis in the Philippines', in P.L. Pingali and P.A. Roger (eds), Impact of Pesticides on Farmers' Health and the Rice Environment, Norwell, MA: Kluwer Academic Publishers and Los Baños, the Philippines: International Rice Research Institute: $344-60$

Raitzer, D.A. (2008) Assessing the Impact of CIFOR's Influence on Policy and Practice in the Indonesian Pulp and Paper Sector, Bogor, Indonesia: Impact Assessment Paper, Center for International Forestry Research (CIFOR)

Ryan, J.G. (1999a) Assessing the Impact of Rice Policy Changes in Vietnam and Contribution of Policy Research, Impact Assessment Discussion Paper 8, Washington DC: International Food Policy Research Institute (IFPRI)

Ryan, J.G. (1999b) Assessing the Impact of Policy Research and Capacity Building by IFPRI in Malawi, Impact Assessment Discussion Paper 11, Washington DC: International Food Policy Research Institute (IFPRI)

Ryan, J.G. and Garrett, J.L. (2003) The Impact of Economic Policy Research: Lessons on Attribution and Evaluation from IFPRI, Impact Assessment Discussion Paper 20, Washington DC: International Food Policy Research Institute (IFPRI)

Shideed, K.; Mazid, A.; Ahmed, M.A.M. and Zahir, Z. (2008) 'Policy Influence and Returns to Policy-oriented Agricultural Research: The Case of Barley Fertilization in Syria', unprocessed manuscript, International Center for Agricultural Research in the Dry Areas (ICARDA) and the Syrian Ministry of Agriculture and Agrarian Reform (SMAAR): Aleppo and Damascus, Syrian Arab Republic Siebeck, W. and Barton, J. (1992) 'The Implications of Applying the Legal Concept of Trust to Germplasm Collections at CGIAR Research Centres', Diversity 8.3: 29-35

Sumner, A.; Ishmael-Perkins, N. and Lindstrom, J. (2009) Making Science of Influencing: The Impact of Development Research, IDS Working Paper 335, Brighton: IDS

Sumner, Andy; Masset, E. and Mulmi, R. (2010 forthcoming) Does Research Reduce Poverty?, ALINe Working Paper

Surani, E. (2003) Research Influence on Policy: The Greywater Reuse Case of Jordan, final report submitted to International Development Research Centre (IDRG), Ottowa

Templeton, D. and Jamora, N. (2008) 'Economic Assessment of Policy-oriented Research on the Private Health Costs of Pesticide Use in the Philippines', in CGIAR Science Council, Impact Assessment of Policy-Oriented Research in the CGIAR: Evidence and Insights from Case Studies, study commissioned by the Science Council Standing Panel on Impact Assessment, Rome: CGIAR Science Council Secretariat

Timmer, C.P. (1998) Adding Value through Policyoriented Research: Reflections of a Scholarpractitioner, Impact Assessment Discussion Paper 4, Washington DC: International Food Policy Research Institute (IFPRI)

Urban Harvest (2005) Urban Agriculture in Kampala, Uganda: Health Impact Assessment and Options for Improvements, final report to the CGIAR-Canada Linkage Fund of the Canadian International Development Agency (CIDA), International Potato Center (CIP), Lima

Van Nostrand, J. (1994) 'Kampala Urban Study: Final Report Part II: Structure Plan', unpublished report by Van Nostrand Associates Ltd for Uganda Ministry of Lands, Housing and Urban Development

Weiss, C.H. and Bucuvalas, M.J. (1980) 'Truth Tests and Utility Tests - Decision-Makers Frames of Reference for Social-Science Research', American Sociological Review 45.2: 302-31 